\title{
Enhancing Students' Literacy Skills through the use of English Storybooks
}

\author{
I Putu Andre Suhardiana, Ni Luh Gede Windy Lestari \\ Universitas Hindu Negeri IGBS Denpasar \\ Email: putuandresuhardiana@gmail.com, windylestari1199@gmail.com
}

\begin{abstract}
Basically, education holds a huge influence on the outcome of the students in the process of learning. One obstacle in education today is concerning students' literacy skill. Most of them possess a low interest in literacy. The strategy that can be adopted to enhance students' literacy is through the use of storybooks. Numerous storybooks and various activities are provided in order to solve this difficulty, particularly in English education as a foreign language. The storybook can simplify the understanding of the foreign language. The stories are educational materials that provide effective learning with reality, recognition, and entertainment. The objective of this study is to enhance the literacy skills of students by using English storybooks, specifically for young learners and accommodate the widest opportunity for teachers to develop their English teaching abilities in such a way that in the future they are better prepared and alert in dealing with the identical situations.
\end{abstract}

Keywords: Literacy Skills, English Storybooks.

\section{INTRODUCTION}

The world educational development is increasingly growing as it marks in terms of multimedia learning with a mixture of new strategies and theories used by teachers, particularly for teachers who teach the English lessons at Kindergarten and Primary school. Basically, education itself holds a huge influence on the outcome of the students in the process of learning. English subjects need to be implemented early on, though the 2013 Curriculum stated that English is only local content for Kindergarten and Primary school. Khameis (2006, p. 111) asserted that the four skills (reading, writing, speaking and listening) naturally appear together in every English class, even in the EFL context. From those four skills, reading plays a significant role in language learning since it can cover all the other language skills. According to Brown (2000, p. 232), a course that deals with reading skills will further deal with related listening, speaking, and writing skills. Reading is one of the four language skills which are extremely valuable to the students in synthesizing information from the text. It is the principal for independent learning, whether the aim is performing better on academic tasks, learning more about the subject 
matter, and improving language capabilities.

Reading is one of the language skills that enable students easier to understand the information. It also can make them finding new ideas or information which can build up their knowledge. Reading consists of two related processes: word recognition and comprehension. Word recognition refers to the process of perceiving how written symbols correspond to one's spoken language. Meanwhile, comprehension is the process of making sense a words sentences and connected text (Oktarina, 2018). Moreover, we grasp the importance of reading however in the real situation most of the students have moderate reading literacy. The results of Progress in International Reading Literacy (PIRLS) 2011 indicated that the percentage of European students that do not reach a satisfactory level of reading achievement is not negligible: “...on average, $20 \%$ of fourth-graders in participating in European Union countries have low reading literacy skills" (Stancel-Piatak, et al 2013, p. 498 in Nofitarina 2017).

The strategy that can be adopted to enhance students' literacy is through the use of storybooks. The storybook can simplify the understanding of the foreign language. The stories are educational materials that provide effective learning with reality, recognition, and entertainment. Karabacak (2014) stated that the placement of the stories in foreign language teaching provides students to be equipped. It can get the students more straightforward to understand the information and further make them enjoy when reading a book. The stories in a storybook that address the students with dominant verbal intelligence can also establish meaningful learning environments for the students with visual, audial, and kinaesthetic intelligence by the way of adapted different techniques and activities.

This paper intends to enhance the literacy skill of young learners through storybooks and provide ideas for teachers to promote the techniques of Teaching English to Young Learners in such a way that they are better equipped in their teaching practices later on. This writing further explained to the teacher concerning the significance of reading strategies to involve students' participation.

\section{DISCUSSION}

\subsection{The Concept of Language Ability}

According to Vygotsky, language is a tool for expressing ideas and asking questions. the language also produces concepts and categories for thinking (Susanto, 2014: 74).

Language ability is also termed linguistic ability. Language ability is a person's ability to use language to express ideas about oneself, understand others, and learn new vocabulary or other languages. While language/linguistic intelligence is one's intelligence in processing words effectively both verbally and in writing. Language intelligence has 
four skills, namely listening, reading, writing, and counting skills.

\subsection{Literacy Concept}

The word literacy can be interpreted as the ability to read and write, then according to Kuder and Hasit (2002), the notion of developing literacy includes the process of reading, writing, speaking, listening, imagining, and seeing. In the process of reading, a complex process occurs, namely cognitive, linguistic, and social activities. The reader must actively involve previous experiences, thought processes, attitudes, emotions, and interests to understand the reading.

Romdhoni (2013: 90) states that literacy is a social event that involves certain skills, which are needed to convey and obtain information in written form.

This is in line with the opinion of Kern (2000: 16) who defines: Literacy is the use of socially, historically, and culturally-situated practices of creating and interpreting meaning through texts. It entails at least a tacit awareness of the relationship between textual conventions and their contexts of use and, ideally, the ability to reflect critically on those relationships. Because it is purpose sensitive, literacy is dynamic-not static-and variable across and within discourse communities and cultures. It draws on a wide range of cognitive abilities, on knowledge of the written and spoken language, on knowledge of genres, and on cultural knowledge".
Based on the opinions above, basically, it can be explained that literacy is a social event that is equipped with skills to create and interpret meaning through text. Literacy requires a series of abilities to convey and obtain information in written form. Then, in line with that Iriantara (2009: 5), now literacy is not only related to the ability to read and write texts since "text" has expanded its meaning so that it also includes "text" in the form of visual, audiovisual and compilatory dimensions so that in the "text", the cognitive, affective, and intuitive elements also emerge.

In the current technological era, the context of the intellectual tradition of a society can be stated to be a literate culture when the community has utilized the information they can to carry out social communication and science.

Based on the explanation earlier, it can be understood that literacy is a stage of social behavior, namely the ability of individuals to read, interpret, and analyze the information and knowledge they can to give birth to the prosperity of life (superior civilization).

According to Kern (2001, 23), there are seven principles of literacy education, namely, (1) literacy involves interpretation of writers/speakers and readers/listeners participate in interpretations, (2) literacy involves collaboration, (3) literacy involves conventions, (4) literacy involves cultural knowledge, (5) literacy involves reflection and 
self-reflection, and (6) literacy is not limited to language systems (oral/written). Literacy is the ability to identify, determine, find, evaluate, create effectively and organized, using and communicating information to overcome various problems.

From the explanation foregoing, it can be inferred that literacy involves achievement, collaboration, convention, culture, self-reflection, and language systems (language users). These abilities need to be possessed by each individual as a condition for participating in society, and that is part of basic human rights regarding lifelong learning. Literacy activities are synonymous with reading and writing activities. However, literacy further includes how a person communicates in society.

Research shows clearly that good basic literacy skills help children to learn to read more easily and increase children's success rates at school (Senechal \& LeFreve, 2002). The results of a meta-analysis conducted by the National Early Literacy Panel (NELP) in 2008 found that the basic literacy ability predicts future literacy abilities at moderate to high levels. There are 11 variables that can consistently predict future reading achievement. The 11 basic literacy abilities are letter knowledge, phonologic awareness, recognizing letters and objects (rapid automatic naming), writing letters and names themselves, phonological memory, besides writing concepts, written knowledge, reading readiness, language oral, and visual processes.

From the description above, the writer defines basic literacy as the ability of pre-schoolers to base and prepare themselves to learn to read and write in elementary school. Furthermore, from several researchers who identified the basic literacy ability components above, the writer can summarize these components into 5 different components, namely: a) language skills, which include vocabulary and understanding of spoken language, b) phonological awareness, namely the ability to detect, manipulate and analyzing spoken language (distinguishing phonemes, syllables, words), c) reading skills which include the introduction of reading rules, letter knowledge and letter sounds, spelling words, d) writing skills, which include the ability to write letters, own names and words, e) interest/motivation in reading, which is the desire in children to read.

\subsection{Children's Language Development Stage}

According to Piaget and Vygotsky, language development for early childhood is divided into several stages, namely (Madyawati, 2017: 6269).

\section{a. The First Stage (prelinguistic)}

This stage is passed by children at the age of 0-5 months. At the age of 0-2 weeks, the child is able to turn to face the sound source. In children aged 1-2 months, children can 
distinguish syllables. aged 3-4 months the child is able to distinguish male and female voices so that he knows where his mother and father are. Whereas at the age of 5 months children begin to pay attention to intonation and rhythm in speech.

\section{b. The Second Stage}

At this stage, children are aged 5 months - 1 year. At this time the child begins to be active. At the age of 5-6 months, children have begun to understand several meanings of words such as names, invitations, and so forth. At the age of 7-8 months, children are able to recognize the sounds of words for objects that are often taught and introduced by their parents repeatedly. At the age of 8-1 years, children have shown their initiative to communicate by attracting the attention of adults.

\section{c. Linguistic Stage}

At this stage, the children have been able to speak a language that resembles adult speech.

\subsection{Storybooks as Language Learning Materials}

As much as textbooks are widely used in language teaching classes, textbooks alone are not enough to develop language competence. Leisure reading or extensive reading is beneficial for students, whether it is in the linguistic aspect or even in the non-linguistic aspect. By reading many materials with choices, readers can improve general language competence, expand and maintain vocabulary growth, improve writing skills, expand world knowledge, create and maintain motivation to read and develop student autonomy (Maley, 2009).

Storybooks are closely related to extensive reading since these books are generally taken by children to be read as entertainment. Children are attracted to storybooks for various reasons. The narrative nature of the storybook is the main attraction of this genre. According to Ayob (1981), it is easier for children to understand ideas and information through stories where they will be able to connect ideas better than informative texts. A story will allow children to feel, think, and experience. Another factor that contributes to attractiveness is the pictures in storybooks. Children's fiction tends to have a lot of pictures to balance out the simple language used. These images that are related to the text, function as an aid for children to understand the meaning and context of the story. They help in maintaining children's attention and large colored pictures will surely arouse children's interest. Even young readers from older age groups appreciate some of the images incorporated in the book. As mentioned by Hamid and Hassan (2012), children tend to like creative and imaginative elements in reading material. In addition, Hsieh, Wang, and Lee (2011) also showed in their study that storybooks provide more exposure to vocabulary than textbooks. Text in fiction books can be read comfortably and can contribute 
to the development of students' fluency (Hill, 2008).

It is also important to choose storybooks or reading material that is suitable for children. According to Deweerdt (2001), recommended reading courses for children must include an approximately equal balance of four main aspects; input that focuses on meaning, learning that focuses on language, output that focuses on meaning, and development of fluency. Input that focuses on meaning refers to the use of language used by students. Language must contain language features (vocabulary and sentence structure) that can be understood by students with some features that are outside of students' knowledge. Krashen (1982) also points out the importance of appropriate input in the theory of understandable inputs. Input must contain "i" (what students already know) and "+1" (what learners have not yet learned) to enable language acquisition to occur successfully. It is believed that students will not be able to obtain anything if the input (reading material in this case) is too difficult and cannot be understood by students or if the input is too easy.

\subsection{Previous Studies}

Reading frequently to preschool children in the home, in particular, can contribute to giving them the skills they need to be successful in school (Whitehurst, 2001 in Costa 2011). Before the students mastering the other skill, reading is really important to young learners.
Araújo \& Costa (2015) state that Home shared book reading during the preschool years is a strong predictor of students' reading achievement in primary school it can benefit more children. Reading comprehension is a skill of paramount importance in all ELT contexts. "It is the basis of instruction in all aspects of language learning: using textbooks for language courses, writing, revising, developing vocabulary, acquiring grammar, editing, and using computer-assisted language learning programs" (Mikulecky, 2008, p. 1).

According to Bay and Cetin (2014) in his study examined storybook reading strategies of preschool teachers in the USA and Turkey. Two teachers were observed during 30 reading activities in each country. The reading strategies used by the teachers were coded according to material and strategies. The findings indicate that both preschool teachers spent between five and ten minutes per day and they used mostly normal (\%86.6; \%73.3) sized books. This article introduces the use of reading strategies by the preschool teachers in both countries, and it emphasizes the findings from observation of reading activities. The findings of this study show how the teachers in both countries used reading strategies and what the different strategies were in each country.

Karabacak (2014) claim in his research is realized as an experimental study on fifth-grade students and related to present the effect of using 
English storybooks in English language education success of the students. The research has been realized in Controlled Last Test Model which has been a model of the control group that takes place in experimental studies. The working group is formed of first-grade students of Turgut Reis Secondary school which is located at Sultanbeyli Province of İstanbul. It has been determined that using English storybooks in English courses by adapting them to different activities increased success when compared with traditional methods and techniques according to the findings.

\section{CONCLUSION}

Reading is one way to acquire information and it further can address the students to discover innovative ideas that can develop their knowledge. However, some young learners possess a lack of reading literacy. Hence, storybooks become a beneficial strategy to enhance students' reading literacy. According to some research, it can be inferred that using storybooks in learning is highly profitable for students and teachers. There are numerous elements that necessitate being regarded by the teacher when using this strategy, one of them is the teachers should consider children's ages and children's interests in complex books, such as alphabet books, informational books, and folktales. Remarkably, if the teachers perceive the storybooks they demand, they could create an enjoyable atmosphere in the classroom and the students will be enthusiastic to read the storybooks.

\section{REFERENCES}

Araújo \& Costa. (2015). Home Book Reading and Reading Achievement in EU Countries: the Progress in International Reading Literacy Study 2011 (PIRLS). Educational Research and Evaluation, 2015. Vol. 21, Nos. 5-6, 422-438, cited on http://dx.doi.org/10.1080/13803 611.2015.1111803.

Bay \& Cetin. (2017). Storybook Reading Strategies of Preschool Teachers in the USA and Turkey. International Journal of Education and Research. Vol. 2 No. 7 July 2014.

Erkaya, O. R. (2005). Benefits of Using Short Stories in the EFL Context. Asian EFL Journal, 8, 1-13.

Fathurrahman \& Astuty. (2018). Journal of English Language Teaching. Volume 5 No. 2, December 2018. Cited on http://ojs.ikipmataram.ac.id/in dex.php/joelt e-ISSN: 25485865.

Habibi \& Sofwan, (2018). Teachers of English for Young Learners: An Analysis on Their English Proficiency and Profile. Cited on: https://www.researchgate.net/ publication/324184294.

Iriantara, Yosal. 2009. Literasi Media: Apa, Mengapa, dan Bagaimana. Bandung: Simbiosa Rekatama Media. 
Karabacak. (2014). The Effect of Using English Story Books in English Courses by Adapting Them to Different Activities on the Foreign Language Success of the Students. IETC 2014. Procedia - Social and Behavioral Sciences 176 ( 2015 ) 1028 - 1033 Language Complexity. The Elementary School Journal, 85(5), 646-661.

Kern, Richard (2001). Literacy \& Language Teaching. Oxford: Oxford University Press.

Morrow, L. M. (1985). Retelling Stories A Strategy for Improving Young Children's Comprehension, Concept of Story Structure, and Oral.
Oktarina, (2018). Innovative Teaching Strategies for Teaching Reading: Reciprocal Teaching Strategy and Face Story Strategy. JOELE. Vol 1, No 1 (2018).

Senechal, M., \& LeFreve, J. (2002). Parental Involvement in the development of children's reading skill: a five-year longitudinal study. Child Development, 73, 445-460.

Susanto, Ahmad. 2014. Perkembangan Anak Usia Dini: Pengantar Dalam Berbagai Aspeknya. Jakarta:

Kencana Prenadamedia Group. 